\title{
Effects of environmental conditions and standard chlorination practices on the infectivity of Giardia cysts
}

\author{
Gaetan M. Faubert ${ }^{1}{ }_{\text {, Sonia S. Leziy }}{ }^{,}$Agathe Bourassa $^{2}$ \& J. D. MacLean ${ }^{3}$ \\ ${ }^{1}$ Institute of Parasitology, Macdonald College, McGill University, 21111 Lakeshore Road, Ste-Anne-de-Bellevue, Quebec \\ H9X 1C0, Canada \\ ${ }^{2}$ Usine Charles J. Des Baillets, 8585 boul. La Verendrye, Lasalle, Quebec H8N 2K2, Canada \\ ${ }^{3}$ McGill Centre for Tropical Diseases, Montreal General Hospital, 1650 Cedar Avenue, Montreal, Quebec H3G 1A4, Canada
}

\begin{abstract}
Effects of environmental conditions and standard chlorination practices on Giardia muris cysts were examined using infectivity of cysts to mice as a biological indicator. The eosin exclusion assay consistently indicated high levels of cyst viability, despite their total loss of infectivity. Storage of cysts at $4{ }^{\circ} \mathrm{C}$ in dry fecal pellets, or soaked in saline, reduced the infectivity of cysts markedly after $3 \mathrm{~d}$. On the other hand, infectivity of cysts was retained for $20 \mathrm{~d}$ if they were isolated from feces by concentration methods, washed and stored in tapwater or wellwater. Routine chlorination procedures for disinfection of drinking water as performed in a modern water treatment plant had no cysticidal effect. This lack of efficacy was not due to a defect in the well-accepted standard procedures followed at this plant, but probably to the high $\mathrm{pH}$ of raw water These results raise important questions regarding the epidemiology of giardiasis, because the cysts remained infective for at least 3 wk if free of fecal material. Since most municipalities use only chlorine as a disinfectant, this procedure would favor the spreading of giardiasis if the filtration system is faulty or simply non-existent. Finally, the results obtained in this study confirm those obtained previously and indicate that the eosin exclusion assay is not reliable for determination of giardicidal effects of disinfectants.
\end{abstract}

\section{INTRODUCTION}

A recent report of the World Health Organization placed Giardia amongst the top 10 parasites affecting man (Schofield 1985). Giardiasis is also the most frequently diagnosed parasitic infection of humans in the United States and Canada (Owen 1984, Notifiable Diseases Summary 1985). The infection in man is transmitted via the fecal-oral route and frequently via contaminated drinking water (Owen 1984). Dogs and beavers can serve as reservoirs of the infection for humans and, therefore, may contribute along with humans to pollution of waters used for drinking or recreational purposes (Dykes et al. 1980, Faubert et al. 1983, Wallis et al. 1984, Kirkpatrick \& Green 1985). Several outbreaks of giardiasis have been reported in North American cities where water treatment plants were identified as the prime candidates responsible for such epidemics (Brady \& Wolfe 1974, Dykes et al. 1980, Weniger et al. 1983). Inadequate or complete lack of filtration of raw water was associated with these outbreaks. The occurrence of waterborne epidemics of giardiasis has spurred an interest into the effects of environmental conditions and standard water treatment procedures on cyst infectivity.

Grant \& Woo (1978) and Bingham et al. (1979) examined the effects of various environmental conditions on the viability of Giardia cysts. They reported that Giardia cysts were highly susceptible to damage by environmental factors, such as temperature, $\mathrm{pH}$ and the incubation medium. The efficacy of different halogens against Giardia cysts has been recently reviewed by Jarroll et al. (1984). The turbidity of water, $\mathrm{pH}$, temperature, cyst-halogen contact time and concentration should be considered in the employment of these chemicals as disinfectants for drinking water. Using the excystation method, Jarroll et al. (1981) found that, at $25^{\circ} \mathrm{C}$, the cysts of G. lamblia are killed if exposed to $1.5 \mathrm{mg} \mathrm{l}^{-1}$ of chlorine for $10 \mathrm{~min}$ at $\mathrm{pH} 6,7$ or 8 . On the other hand, the cysts remained viable after 
exposure to $1 \mathrm{mg} \mathrm{^{-1 }}$ of chlorine at $5^{\circ} \mathrm{C}$ and the same $\mathrm{pH}$ for $60 \mathrm{~min}$. At this temperature, a higher concentration of chlorine $\left(2 \mathrm{mg} \mathrm{l}^{-1}\right.$, at $\mathrm{pH} 6$ or $\mathrm{pH}$ 7) was needed to kill the cysts after $60 \mathrm{~min}$.

The objectives of this study were 3 -fold: (1) to determine the infectivity of Giardia muris cysts incubated in different media and temperatures; (2) to examine the efficacy of standard chlorination of drinking water, as realised in a modern water treatment facility, on cyst infectivity; and (3) to compare the eosin exclusion assay for cyst viability to a biological assay of cyst infectivity.

\section{MATERIALS AND METHODS}

Parasite. Giardia muris used in this study was originally isolated by Roberts-Thomson et al. (1976) and obtained from B. J. Underdown, McMaster University. The parasite was maintained by $14 \mathrm{~d}$ passages through CD-1 Swiss mice.

Mice. Female CD-1 Swiss mice, aged 6 to $8 \mathrm{wk}$, were used in all experiments (Charles River of Canada Inc., St. Constant, Quebec). Upon arrival from the breeder, mice were screened for Giardia spp. infections by 3 consecutive fecal examinations and microscopical examinations of the small intestines of mice chosen at random. In all cases, mice were free of Giardia infections.

Isolation of cysts. Stools collected from individual mice over a period of $2 \mathrm{~h}$ were weighed, emulsified in $0.85 \%$ saline, layered on sucrose (1.1 specific gravity), and centrifuged at $400 \mathrm{~g}$ for $15 \mathrm{~min}$. Cysts concentrated at the saline-sucrose interface were removed, washed in saline, and centrifuged at $600 \mathrm{~g}$ for $10 \mathrm{~min}$. The number of cysts recovered from each sample was determined using a haemocytometer.

Eosin exclusion assay. Equal volumes $(0.5 \mathrm{ml})$ of a $0.1 \%$ aqueous eosin solution (Eosin $\mathrm{Y}$ vital stain, Sigma Chemical Co.) and cyst suspension were combined and allowed to stand at room temperature for 5 min. Cysts were then examined on a haemocytometer. The percentage of eosin exclusion was measured as the number of unstained cysts per 100 observed cysts.

Use of chlorine as a disinfectant. The routine chlorination and filtration procedures employed in the treatment of drinking water at the water treatment plant for the city of Montreal (I'Usine Charles J. Des Baillets) were followed. Water used for the experiments was collected at the treatment facility $2.4 \mathrm{~km}$ above the Lachine Rapids section of the St. Lawrence river. At the time of chlorination, the raw water had pH 8.24, temperature $6^{\circ} \mathrm{C}$, turbidity 3.1 nephelometric turbidity units (NTU), and total organic carbon concentration $2.73 \mathrm{mg} \mathrm{ml}^{-1}$. After filtration, turbidity was 0.13 NTU.
For the study, 51 of water were collected after filtration through sand filters. Chlorine concentration used in the experiments was $1.18 \mathrm{mgl}^{-1}$, added in the form of sodium hypochlorite to the filtered water, and was similar to that used in the facility on that day. Free and combined residual chlorine concentrations were determined after 10,40 and $60 \mathrm{~min}$ by the method of Palin (1967). Moreover, in order to mimic the chlorination procedure employed at the Charles J. Des Baillets facility, the laboratory-chlorinated water was kept in the dark in a covered water bath at $6{ }^{\circ} \mathrm{C}$. The chlorine effect was neutralized at the end of each contact time by washing the cysts 3 times in distilled water.

Cyst infectivity. Cyst infectivity incubated under various environmental conditions was compared to the infectivity of freshly isolated cysts. In all experiments, mice were each inoculated with 1000 cysts. Six mice per group were used in all experiments, unless stated otherwise. The number of cysts released in feces during the acute phase of the infection (Days 7 to 14 of the infection in CD-1 Swiss mice [Belosevic \& Faubert 1983]), was counted to evaluate cyst infectivity.

\section{EXPERIMENTAL PROTOCOL}

Incubation of cysts in different media. In the first experiment, fecal pellets collected over a $2 \mathrm{~h}$ period were stored at $4{ }^{\circ} \mathrm{C}$ for $30 \mathrm{~d}$ in $0.85 \%$ saline.

In the second experiment, cysts were isolated from the feces by sucrose flotation and were then stored at $4{ }^{\circ} \mathrm{C}$ in tapwater or wellwater. The cysts were stored for various intervals ranging from 3 to $30 \mathrm{~d}$.

Chlorinated water. Cysts isolated by sucrose flotation method (specific gravity 1.1) were washed 3 times in distilled water to eliminate the sucrose effect on $\mathrm{pH}_{\text {, }}$ chlorine and organic matter. Giardia muris at 10000 cysts ml $^{-1}$ were added to 3 test tubes containing chlorinated water at an initial concentration of $1.18 \mathrm{mg}$ $\mathrm{ml}^{-1}$. Contact time was 10,40 and $60 \mathrm{~min}$. The shortest time before the treated water was distributed to consumers was $40 \mathrm{~min}$.

Statistics. Data were analysed using 1-way analysis of variance. A probability level of $p<0.05$ was considered significant.

\section{RESULTS}

\section{Incubation of cysts in different media}

Mice infected with fresh cysts (control) passed $2 \times 10^{6}$ cysts $\mathrm{g}^{-1}$ feces $\mathrm{d}^{-1}$ between Days 7 and 14 postinfection. However, cysts kept in saline at $4^{\circ} \mathrm{C}$ for 3,6 or 15 d were less infective to mice when compared to freshly isolated cysts. The results also show that 
Table 1. Giardia muris. Time study on the infectivity of cysts following incubation in different media

\begin{tabular}{|lccc|}
\hline $\begin{array}{c}\text { Incubation } \\
\text { medium }\end{array}$ & $\begin{array}{c}\text { Days of } \\
\text { storage }\end{array}$ & $\begin{array}{c}\text { Mean \# of } \\
\text { cysts } \mathrm{g}^{-1} \\
\text { feces } \mathrm{d}^{-1} \\
\left(\log _{10}\right)\end{array}$ & $\begin{array}{c}\text { Signi- } \\
\text { ficance }\end{array}$ \\
\hline Fresh cysts & 0 & $6.3 \pm 0.52$ & \\
Feces in & 3 & $1.99 \pm 0.97$ & $\mathrm{p}<0.001$ \\
$0.85 \%$ saline & 6 & $1.54 \pm 1.23$ & $\mathrm{p}<0.001$ \\
& 15 & $1.48 \pm 1.96$ & $\mathrm{p}<0.001$ \\
& 30 & 0 & - \\
Tapwater & 15 & $6.57 \pm 0.32$ & $\mathrm{~ns}$ \\
& 20 & $5.08 \pm 1.45$ & $\mathrm{~ns}$ \\
& 30 & 0 & - \\
Wellwater & 15 & $6.01 \pm 0.52$ & $\mathrm{~ns}$ \\
& 20 & $5.17 \pm 1.33$ & $\mathrm{~ns}$ \\
& 30 & 0 & - \\
Mean number of cysts released by 6 mice & \\
- Values compared to those obtained with fresh cysts \\
\hline
\end{tabular}

cysts stored in saline lost their infectivity (Table 1). On the other hand, cysts kept in tapwater or wellwater produced a normal infection when compared to the control group (fresh cysts). Moreover, the pattern of cyst release was comparable to that previously reported (Belosevic \& Faubert 1983). It is of interest to note that the 6 mice infected with cysts isolated from the feces kept in saline at $4{ }^{\circ} \mathrm{C}$ failed to develop a typical pattern of cyst release.

\section{Chlorinated water}

Despite incubation in a high concentration of free chlorine (1.18 to $0.79 \mathrm{mgl}^{-1}$ ) for $10 \mathrm{~min}$, the cyst infectivity of Giardia muris was not affected. Increase of the cyst-chlorine contact time to 60 min did not affect the original infectivity of the cysts. Since the concentration of free chlorine decreases rapidly with time, the proportion of free and combined chlorine present in the water after 10,40 or 60 min was determined (Table 2 ). Water containing a concentration of $\mathrm{free} / \mathrm{combined}$ chlorine of $0.59 / 0.11 \mathrm{mg} \mathrm{l}^{-1}$ parallels that reaching the consumer. This free/combined chlorine value represents the loss after $1 \mathrm{~h}$ contact with the water.

\section{Eosin exclusion assay vs cyst infectivity}

For all groups, the eosin exclusion assay gave a percentage of cyst viability in excess of $50 \%$ (Table 3 ). Note, however, that cysts incubated in chlorinated water or in feces with saline for $30 \mathrm{~d}$ have lost their infectivity.
Table 2. Giardia muris. Infectivity of cysts in CD-1 mice after incubation in chlorinated water at $6^{\circ} \mathrm{C}$. (Initial concentration $1.18 \mathrm{mg} \mathrm{l}^{-1}$ )

\begin{tabular}{|lccc|}
\hline $\begin{array}{c}\text { Incubation } \\
\text { medium }\end{array}$ & $\begin{array}{c}\text { Cyst-chlorine Free/combined } \\
\text { contact time } \\
\text { chlorine } \\
\left(\mathrm{mg} \mathrm{l}^{-1}\right)\end{array}$ & $\begin{array}{c}\text { Mean \# } \\
\text { cysts } \mathrm{g}^{-1} \\
\text { feces d } \\
\left(\log _{10}\right)\end{array}$ \\
\hline Fresh cysts & 0 & - & $5.23 \pm 1.49$ \\
Chlorinated & 10 & $0.79 / 0.12$ & $5.47 \pm 0.56^{\text {ns }}$ \\
water & 40 & $0.62 / 0.13$ & $5.72 \pm 0.87^{\text {ns }}$ \\
\multicolumn{4}{|l}{} \\
- Mean number of cysts released by 6 mice \\
ns: not significant; $p>0.05$ \\
\hline
\end{tabular}

Table 3. Giardia muris. Comparison of viability of cysts determined by eosin exclusion with cyst infectivity assay in CD-1 mice

\begin{tabular}{|c|c|c|c|}
\hline $\begin{array}{l}\text { Incubation } \\
\text { medium }\end{array}$ & $\begin{array}{l}\text { Days of } \\
\text { storage }\end{array}$ & $\begin{array}{c}\% \text { of cysts } \\
\text { viable as per } \\
\text { eosin exclusion }\end{array}$ & $\begin{array}{c}\text { Infectivity in } \\
\text { CD-1 mice } \\
(\text { Mean \# of cysts } \\
\left.\mathrm{g}^{-1} \mathrm{~d}^{-1}\right)\left(\log _{10}\right)\end{array}$ \\
\hline Fresh cysts & 0 & 95 & $6.30 \pm 0.52^{\bullet}$ \\
\hline $\begin{array}{l}\text { Feces in } \\
0.85 \% \text { saline }\end{array}$ & $\begin{array}{r}6 \\
15 \\
30\end{array}$ & $\begin{array}{l}90 \\
75 \\
65\end{array}$ & $\begin{array}{c}1.54 \pm 1.23 \cdots \\
1.48 \pm 1.96 \cdots \\
0\end{array}$ \\
\hline $\begin{array}{l}\text { Chlorinated } \\
\text { tapwater } \\
\text { - Mean numb } \\
\therefore \text { Significant }\end{array}$ & $\begin{array}{l}\quad \begin{array}{l}15 \\
30\end{array} \\
\text { er of cyst } \\
\text { at } p<0.0\end{array}$ & $\begin{array}{l}\quad \begin{array}{l}95 \\
90\end{array} \\
\text { released by } 6 \mathrm{~m} \\
1\end{array}$ & $\begin{array}{c}6.57 \pm 0.32 \\
0 \\
\text { ice }\end{array}$ \\
\hline
\end{tabular}

\section{DISCUSSION}

This study on the effect of chlorine on Giardia cysts differs from those reported previously (Fair et al. 1948, Bingham et al. 1979, Jarroll et al. 1980a, b, 1981, Rice et al. 1982) in that (1) action of the halogen was examined using filtered raw water, and (2) cyst viability was assessed by infecting mice. The Giardia muris mouse model was used because, first, Rice et al. (1982) suggested it to be a valid model in disinfection studies and, second, since its description by Roberts-Thomson et al. (1976), it has been accepted for the study of human giardiasis.

Routine procedures for treatment of drinking water, except ozonation, at the Charles J. Des Baillets water treatment plant for the City of Montreal were carefully followed in this study. Giardia muris cysts were infective to CD-1 mice after incubation in concentrations of chlorine normally lethal to bacteria. The effects of 
chlorine on $G$. lamblia cysts has been assessed previously under laboratory conditions (Jarroll et al. $1980 \mathrm{a}, \mathrm{b})$. According to Jarroll et al. (1980b), these procedures fail to destroy $G$. lamblia cysts not because of an extreme resistance of the cysts to the halogen, but because of insufficient halogen residuals or contact time. Recently, Jarroll et al. (1984) studied the dynamics of chlorination effects on $G$. lamblia cyst viability. Their results indicate that temperature, $p H$, clarity of water and chlorine concentration and contact time play a role in the inactivation of cysts. Working under laboratory conditions, Jarroll et al. (1981) used Sorensen sodium phosphate buffer to study the cysticidal effect of chlorine. Treatment of cysts with $2 \mathrm{mg} \mathrm{l}^{-1}$ of chlorine at $5^{\circ} \mathrm{C}$ and $\mathrm{pH} 8$ did not affect their viability. Our study, which was done under 'field conditions', confirms these findings, and clearly shows the inefficacy of standard bactericidal chlorination of water.

Chlorine gas reacts rapidly with water to form hypochlorous acid which in turn reacts instantly and reversibly with water to form hypochlorite ions (Fair et al. 1948). The hypochlorous acid and hypochlorite ions together are termed 'free chlorine', and are the principal disinfectants. However, the percentage of free chlorine declines sharply above $\mathrm{pH}$ 7.5. The use of additives to control $\mathrm{pH}$ before, during, or after chlorination appears therefore to be an important step in the treatment of water for drinking purposes. The Charles J. Des Baillets water treatment plant does not use additives to adjust the $\mathrm{pH}$. At the time of the experiments, the $\mathrm{pH}$ of raw water was 8.24 . Thus, in this case, chlorination was performed under less than optimal conditions. However, coagulation, flocculation and sedimentation are also components of the basic technology of water treatment and it is likely that these procedures used in concert with filtration will eliminate Giardia cysts from the water. Since ozonation is part of the routine procedure at the Charles J. Des Baillets, experiments are in progress to determine the efficacy of the combined procedure (ozonation-chlorination) in inactivating Giardia cysts.

Giardia muris cysts stored intact at $4{ }^{\circ} \mathrm{C}$ in moist fecal pellets lose their infectivity after $3 \mathrm{~d}$. In contrast, cysts were infective after $20 \mathrm{~d}$ of storage in tapwater or wellwater $\left(4^{\circ} \mathrm{C}\right)$. Little is known about the factors influencing the spreading of giardiasis in humans and animals. Our findings indicate that 'clean water' preserves the infectivity of Giardia cysts. Thus, if Giardia cysts are present in stools and, by the action of rain or any other means, are washed free from the fecal matter, then contamination would be greater. This might be of particular importance in the Canadian and U.S. Rockies, where waterborne outbreaks of giardiasis have been reported. In rocky terrains, the soil is rather poor in bacteria and other organisms which can break- down organic materials including feces. Since the soil cannot absorb much organic material, rainfall or flooding may create a washing effect on feces containing Giardia cysts, which could reach the streams or lakes widely used in these areas as sources of drinking water. We suggest that this phenomenon may play an important role in the outbreaks of giardiasis in rocky terrains.

Our results indicate that the eosin exclusion assay for cyst viability cannot be related to a biological assay for cyst infectivity. Our results confirm those of Grant \& Woo (1978), and suggest that eosin exclusion is not reliable in determining the efficacy of disinfectants in killing Giardia cysts. We believe that the giardicidal activity of a disinfectant can be accurately measured only by the capacity of treated cysts to infect laboratory animals. The viability of cysts does not necessarily indicate the capacity of Giardia to reproduce or replicate. For example, the cysts present in feces mixed with saline and stored for $3 \mathrm{~d}$ failed to produce a fullfledged infection (Table 1). We have shown previously (Belosevic \& Faubert 1983) that a normal course of infection with $G$. muris can be produced by administration of only 10 cysts per mouse. The Mongolian gerbil can also be used for determining cyst infectivity of the human parasite G. lamblia (Belosevic et al. 1983). These animal models should be used for the determination of the efficacy of water disinfectants in killing Giardia cysts.

Acknowledgements. This work was supported partly by grants from the Medical Research Council of Canada, Natural Sciences and Engineering Research Council of Canada, and the Weston Garfield Foundation (to Drs. Faubert and MacLean). Research at the Institute of Parasitology is supported by funds from the Natural Sciences and Engineering Research Council of Canada and the Fonds Formations des Chercheurs et d'Action Concertée pour l'aide et le soutien à la recherche.

\section{LITERATURE CITED}

Belosevic, M., Faubert, G. M. (1983). Giardia muris: correlation between oral dosage, course of infection, and trophozoite distribution in the mouse small intestine. Exp. Parasitol. 56: 93-100

Belosevic, M., Faubert, G. M., MacLean, J. D., Law, C., Croll, N. A. (1983). G. lamblia infections in Mongolian gerbils: an animal model. J. inf. Dis. 147: 222-226

Bingham, A. K., Jarroll, E. L., Meyer, E. A. (1979). Giardia sp.: physical factors of excystation in vitro, and excystation vs eosin exclusion as determinants of viability. Exp. Parasitol. 47: 284-291

Brady, P. G., Wolfe, J. C. (1974). Waterborne giardiasis. Ann. int. Med. 81: 498-499

Dykes, A. C., Juranek, D. D., Lorenz, R. A., Sinclair, S., Jakubowski, W., Davies, R. B. (1980). Municipal waterborne giardiasis. An epidemiologic investigation. Beavers implicated as a possible source. Ann. int. Med. 92: $165-170$ 
Fair, G. M., Morris, J. C., Change, S. L., Weil, I., Burden, R. P. (1948). The behavior of chlorine as a water disinfectant. J. Am. Wat. Works Ass. 40: 1051-1061

Faubert, G. M., Belosevic, M., Walker, T. S., MacLean, J. D., Meerovitch, E. (1983). Comparative studies on the pattern of infection with Giardia spp. in Mongolian gerbils. J. Parasitol. 69: 802-805

Grant, D. R., Woo, P. T. K. (1978). Comparative studies of Giardia spp. in small mammals in southern Ontario. II. Host specificity and infectivity of stored cysts. Can. J. Zool. 56: 1360-1366

Jarroll, E. L., Bingham, A. K., Meyer, E. A. (1980a). Giardia cyst destruction: effectiveness of six small quantity water disinfection methods. Am. J. Trop. Med. Hyg. 29: 8-11

Jarroll, E. L., Bingham, A. K., Meyer, E. A. (1980b). Inability of an iodine method to destroy completely Giardia cysts in cold water. West. J. Med. 132: 567-569

Jarroll, E. L., Bingham, A. K., Meyer, E. A. (1981). Effect of chlorine on Giardia lamblia cyst viability. Appl. environ. Microbiol. 41: 483-487

Jarroll, E. L., Hoff, J. C., Meyer, E. A. (1984). Resistance of cysts to disinfection agents. In: Erlandsen, S. L., Meyer, A. E. (ed.) Giardia and giardiasis. Plenum Press, New York and London, p. 311-328

Kirkpatrick, C. E., Green IV, G. A. (1985). Susceptibility of domestic cats to infections with Giardia lamblia cysts and trophozoites from human sources. J. clin. Microbiol. 21: $678-680$

Notifiable Diseases Summary (1985). Canada Diseases Weekly Report 11-37: 160

Owen, R. L. (1984). Direct fecal-oral transmission of giardiasis. In: Erlandsen, S. L., Meyer, A. E. (ed.) Giardia and giardiasis. Plenum Press, New York and London, p. 329-339

Palin, A. T. (1967). Methods for the determination, in water, of free and combined available chlorine, chlorine dioxide and chlorite, bromide, iodine and ozone, using diethyl-pphenylene diamine. J. Instn Wat. Engrs 21: 537-547

Rice, E. W., Hoff, J. C., Schaeffer III, F. W. (1982). Inactivation of Giardia cysts by chlorine. Appl. Microbiol. 43: 250-251

Roberts-Thomson, I. C., Stevens, D. D., Mahmoud, A. A. F., Warren, K. S. (1976). Giardiasis in the mouse: an animal model. Gastroenterology 71: 57-61

Schofield, C. J. (1985). Parasitology today: an ambitious project. Parasitol. Today 1: 2

Wallis, P. M., Buchancan-Mappin, J. M., Faubert, G. M., Belosevic, M. (1984). Reservoirs of Giardia spp. in southwestern Alberta. J. Wildl. Dis. 20: 279-283

Weniger, B. G., Blaser, M. J., Gedrose, J., Lippy, E. C., Juranek, D. D. (1983). An outbreak of waterborne giardiasis associated with heavy water runoff due to warm weather and volcanic ashfall. Am. J. Public Health 73: $868-872$ 